\title{
Genetic linkage between Huntington's disease and the DNA polymorphism G8 in South Wales families
}

\author{
PETER S HARPER*, SANDRA YOUNGMAN*, MARY ANNE ANDERSON†, \\ MANSOOR SARFARAZI*, OLIVER QUARRELL*, RUDOLF TANZI†, \\ DUNCAN SHAW*, PEGGY WALLACE , P MICHAEL CONNEALLY \\ AND JAMES F GUSELLA† \\ From ${ }^{*}$ the Section of Medical Genetics, University of Wales College of Medicine, Cardiff, Wales; \\ the Neurogenetics Laboratory, Massachusetts General Hospital, Boston, Massachusetts, USA; and \\ $\ddagger$ the Department of Medical Genetics, Indiana University Medical Center, Indianapolis, Indiana, USA.
}

SUMmARY Analysis of the polymorphism shown by the DNA probe G8 in eight South Wales families with Huntington's disease has confirmed close genetic linkage between this marker and the disorder, the most likely genetic distance being two centimorgans (cM). The closeness of the linkage suggests that G8 may have clinical applications in genetic prediction for this condition.

Close genetic linkage has been established between Huntington's disease (HD) and a polymorphic DNA sequence on chromosome $4, \mathrm{G} 8$, as a result of studies in two large HD kindreds, one from the USA and the other from Venezuela. ${ }^{1}$ No instances of recombination between marker and disease were initially detected in these families, but recombination has been documented subsequently. ${ }^{2}$ The precise genetic distance and the general applicability of the linkage in HD families need to be firmly established if this linkage is to be applied in clinical practice, and the usefulness of the G8 marker will also depend on the proportion of subjects who are heterozygous (and thus informative), and on the pedigree structure of individual families.

We have studied eight South Wales kindreds with HD whose structure appeared to be capable of giving useful linkage information. They form part of a much larger body of 130 families in South Wales ${ }^{3}$ which have been extensively documented and are under prospective surveillance.

\section{Methods}

Venous blood samples $(20 \mathrm{ml})$ were taken into EDTA, with an additional $10 \mathrm{ml}$ heparinised sample being used for setting up of transformed lymphoblastoid cell lines. Samples studied in Boston were transported immediately by air, DNA being isolated

Received for publication 20 June 1985. Accepted for publication 31 July 1985. and cell lines established by methods already described. ${ }^{1}$ DNA from samples studied in Cardiff was isolated by the method of Kunkel et al ${ }^{4}$ and stored at $-20^{\circ} \mathrm{C}$ before analysis.

A total of $5 \mu \mathrm{g}$ DNA was digested to completion using the restriction enzyme HindIII, and Southern blot analysis was performed as described previously.

All affected patients were examined by at least one of us, no family members with equivocal or unknown status being included in the analysis. Unaffected relatives were only included over the age of 40 years, their residual risk of possessing the HD gene being calculated from a life table for age at onset based on our own population. ${ }^{5}$

Genetic linkage analysis of genotype data was carried out by the computer programme LIPED $3 .^{6}$

\section{Results}

Fig 1 shows the alleles detected by pKO82 (a subclone of probe G8) with HindIII digested human DNA. pKO82 detects two polymorphic HindIII sites, the frequency of the rare alleles in 65 normal British subjects being 0.25 and 0.125 for sites 1 and 2 , respectively. The four possible combinations of alleles at site 1 and site 2 are called haplotype A, B, $C$, and D (table 1). Haplotype frequencies observed in the normal British population $(n=65)$ are $A 66 \%$, B $9 \%, C 22 \%$, and D $3 \%$. These are similar frequencies to those observed in 93 unrelated patients affected with HD. 


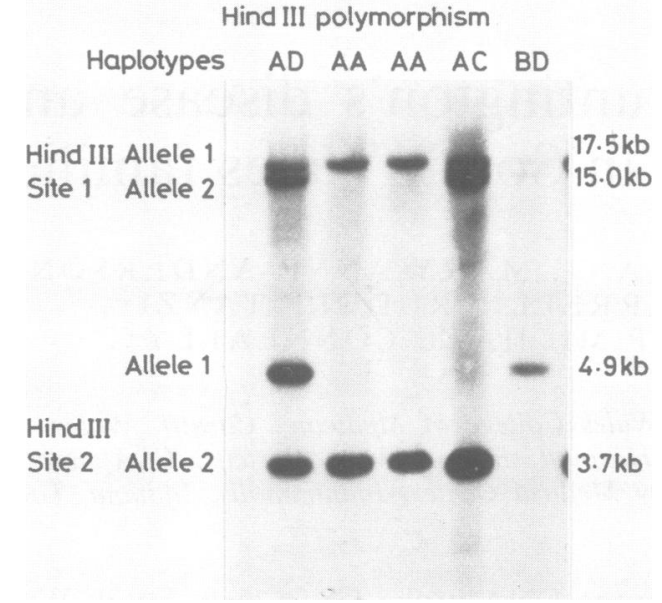

FIG 1 Hybridisation of the probe G8 (subclone pKO82) to HindIII digested human genomic DNA. After digestion of the DNA with the restriction enzyme HindIII, the DNA fragments were separated by electrophoresis on a $0.7 \%$ agarose gel. Blotting of the DNA onto nitrocellulose filters was performed according to the method described by Southern. ${ }^{7}$ The haplotypes observed in each subject were assigned as described previously.'

TABLE 1 Haplotypes at the G8 locus.

\begin{tabular}{llll}
\hline $\begin{array}{l}\text { Haplotype } \\
\text { SindIII }\end{array}$ & $\begin{array}{l}\text { Hity } \\
\text { polymorphism }\end{array}$ & $\begin{array}{l}\text { Haplotype } \\
\text { frequency }\end{array}$ \\
\cline { 2 - 3 } & Site 1 & Site 2 & \\
\hline A & - & + & 0.66 \\
B & - & - & 0.09 \\
C & + & + & 0.22 \\
D & + & - & 0.03 \\
\hline
\end{tabular}

+ and - denote presence or absence of the HindIII restriction sites, as designated by Gusella et al. '

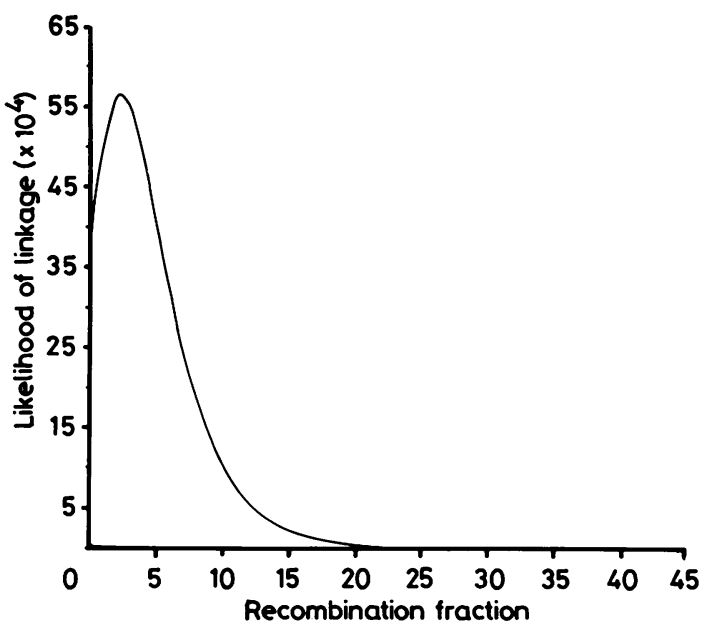

FIG 2 The probability of linkage at various recombination fractions between Huntington's disease and the $G 8$ probe.

Table 2 shows the lod scores denoting probability for different recombination fractions $(\theta)$; the max imum value of $\theta$ is at $2 \mathrm{cM}$ (fig 2) and we have found no evidence of heterogeneity between families.

Fig 3 shows the pedigree of one informative family in which the HD gene is transmitted along with the rare $B$ haplotype. In the other families studied the commonest (A) haplotype was segregating with $\mathrm{HD}$.

\section{Discussion}

Our results show that the close linkage between HD and the DNA polymorphism G8, initially reported

TABLE 2 Lod scores for $H D$ and G8.

\begin{tabular}{|c|c|c|c|c|c|c|c|c|c|c|c|}
\hline & & \multicolumn{10}{|c|}{ Recombination fraction $(\theta)$} \\
\hline & & 0.01 & 0.05 & $0 \cdot 10$ & $0 \cdot 15$ & 0.20 & 0.25 & $0 \cdot 30$ & $0 \cdot 35$ & 0.40 & 0.45 \\
\hline Family & 1 & $0 \cdot 110$ & $0 \cdot 101$ & $0 \cdot 087$ & 0.073 & $0 \cdot 059$ & $0 \cdot 047$ & $0 \cdot 035$ & $0 \cdot 025$ & $0 \cdot 016$ & 0.008 \\
\hline & 2 & 0.077 & 0.064 & 0.049 & 0.036 & $0 \cdot 026$ & $0 \cdot 017$ & $0 \cdot 011$ & 0.006 & 0.003 & 0.001 \\
\hline & 3 & -0.037 & -0.021 & -0.006 & 0.003 & 0.008 & 0.010 & 0.009 & 0.006 & 0.003 & 0.001 \\
\hline & 4 & 0.864 & 0.770 & 0.647 & 0.525 & 0.408 & $0 \cdot 300$ & $0 \cdot 205$ & $0 \cdot 124$ & $0 \cdot 062$ & $0 \cdot(020$ \\
\hline & 5 & 0.659 & 0.591 & $0 \cdot 508$ & 0.428 & $0 \cdot 351$ & $0 \cdot 279$ & $0 \cdot 212$ & $0 \cdot 150$ & 0.094 & 0.043 \\
\hline & 6 & -0.065 & $0 \cdot 326$ & $0 \cdot 384$ & 0.337 & 0.256 & $0 \cdot 173$ & $0 \cdot 102$ & $0 \cdot 052$ & 0.021 & 0.005 \\
\hline & 7 & $0 \cdot 454$ & $0 \cdot 396$ & $0 \cdot 326$ & $0 \cdot 262$ & $0 \cdot 204$ & $0 \cdot 153$ & $0 \cdot 109$ & $0 \cdot 072$ & $0 \cdot 042$ & $0 \cdot 018$ \\
\hline & 8 & $3 \cdot 611$ & $3 \cdot 340$ & $2 \cdot 987$ & $2 \cdot 615$ & $2 \cdot 223$ & $1 \cdot 810$ & $1 \cdot 374$ & 0.924 & $0 \cdot 483$ & $0 \cdot 135$ \\
\hline Total & & $5 \cdot 673$ & $5 \cdot 567$ & 4.982 & $4 \cdot 279$ & 3.535 & 2.789 & $2 \cdot 057$ & $1 \cdot 359$ & 0.724 & 0.231 \\
\hline
\end{tabular}




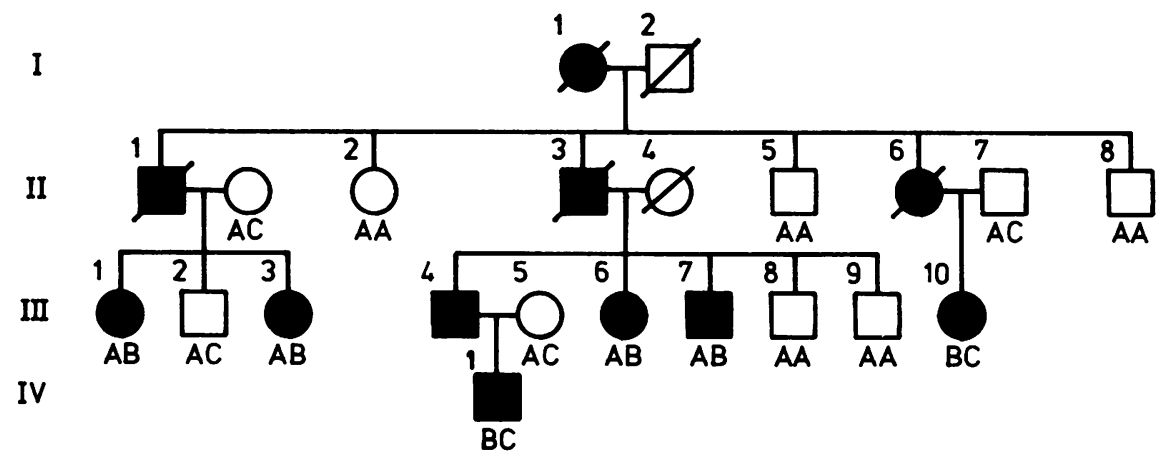

FIG 3 A South Wales kindred with HD, showing transmission of haplotype $B$ with the disorder.

for two large kindreds from the USA and Venezuela, appears to apply also to families in South Wales. Although the relatively small size of these kindreds gives a lower lod score for each, the combined probability is high, with no unequivocal recombination seen between marker and disease. Nor do our families suggest heterogeneity, an important point if this approach is to have general application in prediction.

The population frequency of marker types in the normal UK population appears very similar to that reported by Gusella et al for the USA. Combining the HindIII with a further three polymorphisms at the G8 locus (using restriction enzymes EcoRI, Nci1, and Pst 1$),{ }^{8}$ over $80 \%$ of subjects are heterozygous at the G8 locus, and are thus potentially informative for its use in genetic prediction.

Before we can consider using the G8 probe as a predictive marker in families, further work is required to establish the precise genetic distance. The most likely current estimate, based on the original published families, those reported here, and others studied from the USA (Gusella et al, in preparation), is approximately $5 \mathrm{cM}$, suggesting that it will form a predictive test with an accuracy of around $95 \%$. A more accurate prediction will be feasible when markers are available on the opposite side of HD to the G8 locus. Limitations arising from subjects not being heterozygous are likely to be reduced by the discovery of further polymorphisms at the G8 and adjacent loci, so that the major limitation is likely to be the structure of individual families, in particular the absence of living key members such as affected parents or grandparents. The extent of such limitations in the South Wales population is discussed elsewhere. ${ }^{9}$

Study of the G8 probe in chorionic villus biopsies has shown it to be reliably detectable in such samples, ${ }^{10}$ so that this approach is feasible in principle for prenatal prediction in early pregnancy. However, we would not advise clinical application of the linkage until the results of more extensive family studies are available.

Despite these reservations it seems clear that the genetic linkage between HD and G8 is both close and likely to be of general application. It represents an important step towards identification of the HD gene itself and may well prove to be of use in selected families for genetic prediction.

We thank Mrs Morag Nordin, Mrs Pat Jones, and Miss Audrey Tyler for their help in obtaining blood samples and in documenting the families, and we are grateful to the families themselves for their cooperation. This work was supported by grants from the Medical Research Council of Great Britain and the Hereditary Disease Foundation.

\section{References}

1 Gusella JF, Wexler NS, Conneally PM, et al. A polymorphic DNA marker genetically linked to Huntington's disease. Nature 1983;306:244-4.

2 Gusella JF, Tanzi RE, Anderson ME, et al. DNA markers for nervous system diseases. Science 1984;225:1320-6.

3 Harper PS, Tyler A, Smith S, Jones P, Newcombe RG, McBroom V. A genetic register for Huntington's chorea in South Wales. J Med Genet 1982;19:241-5.

4 Kunkel LM, Smith KD, Boyer SH, et al. Analysis of human Ychromosome-specific reiterated DNA in chromosome variants. Proc Natl Acad Sci USA 1977;74:1245-9.

5 Newcombe RG. A life table for onset of Huntington's chorea. Ann Hum Genet 1981;45:375-85.

6 Ott J. Estimation of the recombination fraction in human pedigrees: efficient computation of the likelihood for human linkage studies. Am J Hum Genet 1974;26:588-97. 
${ }^{7}$ Southern EM. Detection of specific sequences among DNA fragments separated by gel electrophoresis. J Mol Biol 1975;98:503-17.

' Gusella JF, Gibbons K, Hobbs W, et al. The G8 locus linked to Huntington's disease. Am J Hum Genet 1984;36:139.

${ }^{9}$ Harper PS, Sarfarazi M. Genetic prediction and family structure in Huntington's chorea. $\mathrm{Br}$ Med $J$ (in press).
10 Upadhyaya M, Harper PS. DNA studies and fetal sexing using chorionic villi. Hum Genet (in press).

Correspondence and requests for reprints to Professor P S Harper, Section of Medical Genetics, University of Wales College of Medicine, Heath Park, Cardiff CF4 4XN. 